\title{
PEMERIKSAAN PERKARA PELANGGARAN \\ LALU LINTAS BERDASARKAN PERMA NO. 12 TAHUN 2016 TENTANG TATA CARA PENYELESAIAN PERKARA LALU LINTAS
}

\author{
Gatot Haryono \\ Fakultas Hukum Magister Ilmu Hukum, Universitas Airlangga \\ e-mail: gatot.sby1980@gmail.com
}

\begin{abstract}
ABSTRAK
Proses penyelesaian perkara pelanggaran berdasarkan Perma No. 12 Tahun 2016 yaitu pelanggar cukup melihat secara online atau dapat melihat langsung di papan pengumuman yang ada di Pengadilan Negeri untuk mengetahui putusan atas pelanggaran yang telah dilakukan. Setelah pelanggar mengetahui hasil putusan hakim yang biasanya berupa denda yang harus dibayar, selanjutnya pelanggar dapat membayar denda tersebut ke Bank BRI atau membayar langsung ke Kejaksaan untuk selanjutnya mengambil barang bukti di Kejaksaan. Masih terdapat banyak kekurangan dalam penerapan Perma No. 12 Tahun 2012, salah satunya terkait dengan pelaksanaan penyelesaian perkara pelanggaran lalu lintas tanpa hadirnya pelanggar. Permasalahannya adalah bagaimana jika pelanggar yang ditilang tidak merasa bersalah, pelanggar tidak dapat melakukan pembelaan diri karena proses penyelesaian pelanggaran lalu lintas dilaksanakan tanpa kehadiran pelanggar. Sesuai Perma No. 12 Tahun 2016, upaya hukum berupa perlawanan (verzet) hanya dapat dilakukan ketika pidana yang dijatuhkan berupa pidana perampasan kemerdekaan dan bukan pidana denda. Jadi apabila hanya dikenakan pidana denda, maka pelanggar tidak dapat melakukan upaya hukum. Salah satu yang didapat dari penelitian ini, yaitu terhadap putusan (yang sudah berkekuatan hukum tetap) termasuk dan tidak terbatas pada putusan (verstek) perkara tilang yang menjatuhkan pidana denda, apabila pelanggar merasa keberatan, tentu ada upaya hukum yang dapat dilakukan, yaitu upaya hukum luar biasa (berupa Peninjauan Kembali).
\end{abstract}

Kata Kunci: pemeriksaan perkara; pelanggaran lalu lintas; upaya hukum

\begin{abstract}
The violation case settlement process is based on Perma No. 12 of 2016, offenders be able to see online, or directly on the notice board in the District Court to find out the results of the judge's decision on violations that have been committed by the violator. After the violator knows the judge's decision which is usually in the form of a fine that must be paid, then the violator can pay the fine to BRI Bank or pay directly to the prosecutor to then take the evidence at the prosecutor's office. There are still many shortcomings in the application of Perma No. 12 of 2012, one of which is related to the implementation of settlement of traffic violation cases without the presence of violators. The problem is what if the ticketed offender does not feel guilty, the offender will not be able to defend himself because the process of resolving traffic violations is carried out without the presence of the violator. As per Perma No. 12 of 2016, legal efforts in the form of resistance (verzet) can only be carried out when the sentence imposed is in the form of a criminal offense of freedom and not a criminal fine. So if only a criminal fine is imposed, the offender cannot make a legal effort. One of the results of this study, which is on decisions (which have permanent legal force) includes and is not limited to verstek cases that impose criminal penalties, if the offender has objections, there is certainly a legal effort that can be taken, namely legal efforts extraordinary (in the form of a Review).
\end{abstract}

Keywords: examination of the cases; traffic violations; legal effort 


\section{PENDAHULUAN}

Untuk mencegah semakin banyaknya kecelakaan lalu lintas, pemerintah melalui Kepolisian semakin gencar mengingatkan kepada semua masyarakat tentang pentingnya kedisiplinan dalam berlalu lintas. Pemerintah banyak mengeluarkan kebijakan khususnya melalui aparat penegak hukum terkait dengan kedisiplinan dalam berlalu lintas. Kebijakan ini mengedepankan pendekatan persuasif edukatif, diantaranya melalui pendidikan disiplin berlalu lintas sejak dini, program pencegahan, safety riding dan safety driving. Penindakan pelanggaran dilakukan secara selektif dangan mengutamakan pada pelanggaran yang sifatnya membahayakan keselamatan berlalu lintas. Untuk mengurangi angka kecelakaan dan pelanggaran lalu lintas, diperlukan kesadaran hukum pada masing-masing pengendara kendaraan bermotor. Pengendara yang mempunyai kesadaran hukum penuh dalam berkendara dan mengikuti prosedur berkendara dengan baik akan senantiasa terdorong untuk tertib pada peraturan lalu lintas yang ada.

Berbicara tertib lalu lintas dengan menggunakan pendekatan sistem, maka ada beberapa komponen yang harus diperhatikan. Komponen aparat lalu lintas, komponen prasarana dan sarana lalu lintas, serta jangan dilupakan komponen kesadaran masyarakat berlalu-lintas merupakan komponen-komponen yang menciptakan suasana tertib berlalu lintas. ${ }^{1}$

Adanya penegakan hukum diyakini dapat meningkatkan kesadaran hukum masyarakat dalam berkendara. Penindakan secara tegas yang dilakukan oleh pihak kepolisian terhadap para pelanggar aturan lalu lintas merupakan salah satu cara untuk mengurangi angka kecelakaan lalu lintas. Salah satunya menindak para pelanggar lalu lintas dengan tilang. Diharapkan bagi aparat pengak hukum benarbenar menerapkan aturan yang berlaku terkait dengan tilang, sehingga tidak ada yang namanya tilang titipan seperti yang biasa dikenal dalam masyarakat, dengan kata lain pelanggar dapat memberikan suap kepada pihak kepolisian yang melakukan penindakan terhadap pelanggar lalu lintas. Hal-hal seperti ini yang mengakibatkan semakin maraknya

1 Ari Purwadi. (1997). "Displin Lalu Lintas dan Problemanya". Perspektif. Volume 2 No. 1 Tahun 1997 Edisi April. h. 13-22. DOI: http://dx.doi.org/10.30742/perspektif. v2i1.127 perkara pelanggaran lalu lintas, para pelanggar lalu lintas berfikir bahwa mereka dapat dengan mudah menyelesaikan perkara pelanggaran lalu lintas tanpa harus mengikuti proses-proses sebagaimana yang telah diatur undang-undang, mereka berfikir bahwa dengan cara menitipkan uang denda kepada pihak yang berwajib sudah bisa selesai perkaranya.

Untuk mengatasi maraknya hal-hal seperti di atas, Mahkamah Agung (MA) telah menerbitkan Peraturan Mahkamah Agung (Perma) Nomor 12 Tahun 2016 tentang Tata Cara Penyelesaian Pelanggaran Lalu Lintas. Hal paling mendasar diterbitkannya Perma No. 12 Tahun 2016 tersebut adalah untuk menghindari maraknya penyuapan terhadap polisi dalam melakukan penindakan terhadap pelanggar lalu lintas, selain itu proses penyelesaian dalam perkara pelanggaran lalu lintas dianggap belum optimal sehingga perlu dilakukan pengaturan agar keadilan dan pelayanan publik dapat dirasakan oleh masyarakat sebagai pencari keadilan.

Hal penting yang diatur dalam Perma No. 12 Tahun 2016 ini adalah mengenai tata cara pembayaran sanksi denda oleh pelanggar yang langsung dapat disetor ke Bank Rakyat Indonesia (BRI) sesuai besaran denda yang dijatuhkan. Pelanggar tidak perlu lagi antri di pengadilan untuk menghadiri persidangan. Pelanggar hanya perlu datang ke kejaksaan untuk mengambil barang bukti yang disita oleh kepolisian dengan menunjukkan bukti pembayaran yang telah dilakukan di bank.

Terkait dengan berkas perkara pelanggaran lalu lintas, Perma ini juga mengatur daftar berkas tilang yang juga dilakukan secara elektronik dalam jaringan (daring) internet atau online dengan jangka waktu tiga hari sebelum sidang perkara tilang. Yang menjadi pertanyaan disini adalah apakah yang menjadi dasar pertimbangan hakim dalam menjatuhkan besaran denda terhadap masing-masing pelanggar lalu lintas.

\section{PERUMUSAN MASALAH}

Bagaimanakah efektivitas penjatuhan sanksi pidana terhadap pelanggar lalu lintas berdasarkan Perma No. 12 Tahun 2016.

\section{PEMBAHASAN}

Penyelesaian Perkara Lalu Lintas Sebelum Dikeluarkannya Perma No. 12 Tahun 2016 
Pada dasarnya program kegiatan penegakan hukum bukan berorientasi mencari kesalahan dari pengguna jalan tetapi lebih berorientasi pada perlindungan, pengayoman dan pelayanan pengguna jalan yang melanggar itu sendiri (penindakan pelanggaran helm, sabuk pengaman, dan kelengkapan kendaraan bermotor), pengguna jalan lainnya (penindakan pelanggaran SIM, Kecepatan, rambu, marka dan lainnya) serta kepentingan pengungkapan kasus pidana (penindakan pelanggaran STNK, nomor rangka, nomor mesin dan lainnya). ${ }^{2}$ Pada dasarnya peran awal dalam penanganan perkara pelanggaran lalu lintas dilakukan oleh kepolisian. Pada proses pelaksanaan acara cepat terdapat beberapa karakteristik khusus hukum acara, dibandingkan dengan bentuk acara lainnya. Beberapa bentuk kekhususan dari acara cepat adalah proses pelimpahan perkara tidak dilakukan melalui aparat penuntut umum, tetapi penyidik bertindak sebagai kuasa penuntut umum, tidak diperlukan adanya surat dakwaan, dilakukan dengan hakim tunggal, saksi tidak mengucapkan sumpah, dan sifat putusan bersifat final dan mengikat. Hal ini didasarkan pada ketentuan Pasal 205 ayat (2) KUHAP, yang menyatakan bahwa: "Dalam perkara sebagaimana dimaksud dalam ayat (1), penyidik atas kuasa penuntut umum, dalam waktu tiga hari sejak berita acara pemeriksaan selesai dibuat, menghadapkan terdakwa beserta barang bukti, saksi, ahli, atau juru bahasa ke sidang pengadilan."

Beberapa konsekuensi dari hal ini adalah sebagai berikut:

a. Penyidik mengambil alih wewenang penuntut umum, atau wewenang penuntut umum sebagai aparat penutut dilimpahkan undang-undang kepada penyidik;

b. Dengan pelimpahan wewenang tersebut, penyidik "atas kuasa" penuntut umum: i. melimpahkan berkas perkara langsung ke pengadilan tanpa melalui aparat penuntut umum; ii. berwenang langsung menghadapkan terdakwa beserta barang bukti, saksi, ahli, atau juru bahasa yang diperlukan ke sidang pengadilan.

c. Pelimpahan atas kuasa penuntut umum kepada penyidik dalam acara pemeriksaan tindak pidana ringan adalah "demi hukum". Berdasarkan

\footnotetext{
${ }^{2}$ Farouk Muhammad. (1999). Praktik Penegak Hukum (Bidang Lalu Lintas). Jakarta: Balai Pustaka, h. 33.
}

penegasan penjelasan Pasal 205 ayat (2): yang dimasud "atas kuasa" dari penuntut umum kepada penyidik adalah "demi hukum". Ini memang logis. Bukankah pelimpahan wewenang tersebut berdasar ketentuan undang-undang? Sehingga penyidik dalam hal ini bertindak atas "kuasa undang-undang" dan tidak memerlukan surat kuasa khusus lagi dari penuntut umum.

d. Tidak mengurangi hak penuntut umum untuk menghadiri pemeriksaan sidang. ${ }^{3}$

Walaupun undang-undang telah menyerahkan wewenang pelimpahan berkas dan menghadapkan orang-orang yang diperlukan ke sidang pengadilan oleh penyidik atas kuasa penuntut umum, tidak menghilangkan hak penuntut umum untuk menghadiri pemeriksaan di sidang pengadilan.

Karakteristik khusus dari hukum acara cepat kedua adalah tidak diperlukannya surat dakwaan di dalam proses penuntutan. Proses pendakwaan hanya dicatatkan di dalam buku register. Hakim yang memimpin jalannya persidangan pada hukum acara cepat cukup dipimpin oleh hakim tunggal saja. Hal ini mengingat sederhananya penerapan hukum dan penilaian terhadap fakta dari proses peradilan cepat. ${ }^{4}$ Hal-hal khusus lainnya yang terdapat dalam acara cepat adalah proses pembuktian, pada proses acara cepat, bukti-bukti yang disajikan hanya terdapat pada kesaksian dari penyidik dan/atau pelanggar sendiri, tanpa didukung oleh alat bukti lainnya. Sehingga, keyakinan hakim sangat berpengaruh untuk menentukan bersalah atau tidaknya seorang terdakwa. Terkait dengan hal ini, Yahya Harahap memberikan kritik, bahwa dalam perkara cepat, walaupun memiliki standar pembuktian yang jauh lebih rendah dibandingkan dengan Pasal 183 KUHAP, keyakinan hakim semata tidak dapat dijadikan dasar untuk menjatuhkan putusan kepada pelanggar tetapi harus juga didukung oleh alat bukti lainnya. ${ }^{5}$ Pada dasarnya sifat putusan hakim Pengadilan Negeri dari acara cepat adalah pertama dan terakhir, sebagaimana dimaksud dalam Pasal 250 ayat (3) KUHAP. Yahya Harahap memberikan pengertian, terhadap hal tersebut, sebagai berikut: 1. Putusan Pengadilan

\footnotetext{
${ }^{3}$ Tim Peneliti. (2015). Standarisasi Pengelolaan Perkara Pelanggaran Lalu Lintas di Pengadilan Negeri. Jakarta: Pusat Studi Hukum dan Kebijakan Indonesia, h. 33.

${ }^{4}$ ibid., h. 34.

${ }^{5}$ ibid.
} 
Negeri bersifat putusan tingkat terakhir, di mana tidak dapat diupayakan upaya hukum banding pasca dihukumnya seorang pelanggar; 2. Namun demikian, kasasi dapat dilakukan berdasarkan ketentuan Pasal 244 KUHAP.

Minimnya pengaturan mengenai penanganan perkara pelanggaran lalu lintas juga terlihat dalam peraturan turunan undang-undang tersebut. Peraturan Pemerintah No. 80 Tahun 2012 tentang Tata Cara Pemeriksaan Kendaraan Bermotor di Jalan dan Penindakan Pelanggaran Lalu Lintas dan Angkutan Jalan mengatur mengenai persidangan dan pembayaran denda pelanggaran. Namun, peraturan ini tidak banyak mengatur mengenai pelaksanaan sidang. Hanya terdapat tiga ketentuan yang secara langsung berhubungan dengan prosedur pelaksanaan sidang, yaitu: 1. Penyerahan surat tilang dan alat bukti yang harus dilakukan dalam waktu paling lambat 14 hari sejak terjadinya pelanggaran (Pasal 29 ayat (1)); 2. Pelaksanaan sidang sesuai dengan hari sidang yang disebutkan dalam surat tilang (Pasal 29 ayat (3)); dan 3. Persidangan dapat dilakukan dengan atau tanpa kehadiran pelanggar atau kuasanya (Pasal 29 ayat (4)). ${ }^{6}$

Ketentuan-ketentuan sebagaimana tersebut di atas belum cukup menjelaskan bagaimana Pengadilan harus melakukan pengelolaan atau mengatur prosedur penyelesaian perkara pelanggaran lalu lintas. Prosedur penanganan perkara pelanggaran lalu lintas sebelumnya juga diatur dalam Surat Kesepakatan Bersama antara Ketua Mahkamah Agung, Menteri Kehakiman, Jaksa Agung, dan Kepala Kepolisian tentang Tata Cara Penyelesaian Perkara Pelanggaran Lalu lintas Jalan Tertentu yang ditandatangani pada 19 Juni 1993. Kesepakatan bersama ini juga mengatur mengenai Acara Pemeriksaan Perkara Pelanggaran Lalu Lintas yang meliputi: ${ }^{7}$

a. Penyidik memberitahukan kepada pelanggar tentang hari, tanggal, jam, dan tempat ia harus menghadap ke Sidang Pengadilan;

b. Pelanggar dapat menunjuk seorang wakil yang disediakan oleh Kepolisian dengan Surat Tilang untuk mewakilinya di sidang Pengadilan;

c. Pelanggar atau wakilnya menerima putusan hakim;

\footnotetext{
6 ibid.

${ }^{7}$ ibid., h. 36.
}

d. Selanjutnya berlaku ketentuan sebagaimana tersebut pada Pasal 214 UU No. 8 Tahun 1981 tentang Hukum Acara Pidana;

e. Petugas Kejaksaan Negeri sebagai eksekutor memberitahukan dan menyerahkan lembar blanko tilang warna merah dan biru kepada BRI bahwa uang titipan atas nama pelanggar yang telah disetorkan, telah berubah menjadi uang denda dan biaya perkara agar disetorkan ke Kas Negara.

Isi dari surat kesepakatan tersebut merujuk pada Pasal 214 KUHAP yang mengatur mengenai pemeriksaan acara cepat. Dari uraian sebelumnya, ketentuan penanganan perkara tilang belum memperlihatkan pengaturan teknis terhadap penyelenggaran sidang tilang oleh Pengadilan. Dari penelusuran terhadap prosedur pelaksanaan sidang tilang yang tersedia di website Pengadilan Negeri, secara umum terdapat empat tahapan yang dilalui pelanggar untuk menjalani proses persidangan tindak pelanggaran lalu lintas di Pengadilan. Tahapan tersebut meliputi: 1. Pendaftaran; 2. Pelaksanaan sidang; 3. Pembayaran denda; 4. Pengambilan barang bukti.

Beberapa bentuk kekhususan lainnya dari pemeriksaan pelanggaran lalu lintas dengan acara cepat adalah proses pelimpahan perkara tidak dilakukan melalui aparat penuntut umum, tetapi penyidik bertindak sebagai kuasa penuntut umum, tidak diperlukan adanya surat dakwaan, dilakukan dengan hakim tunggal, saksi tidak mengucapkan sumpah, dan sifat putusan bersifat final dan mengikat. $^{8}$

\section{Penjatuhan Sanksi Pidana Terhadap Pelanggar Lalu Lintas Setelah Dikeluarkannya Perma No. 12 Tahun 2016}

Dengan diterbitkannya Perma No. 12 Tahun 2016 diharapkan dapat mempercepat dan mempermudah proses penyelesaian perkara tilang. Menurut Kepala Biro Hukum dan Humas MA, Ridwan Mansyur mengungkapkan ada beberapa poin penting yang termuat dalam Perma No. 12 Tahun 2016. Beberapa poin adalah pelanggar tidak perlu lagi hadir di sidang pengadilan, kecuali apabila pelanggar ingin

\footnotetext{
${ }^{8}$ M. Yahya Harahap. (2010). Pembahasan Permasalahan dan Penerapan KUHAP. Cetakan ke 12. Jakarta: Sinar Grafika, h. 423 .
} 
mengajukan keberatan atas penetapan/putusan terkait perampasan kemerdekaan. Hal ini untuk menekan praktik percaloan perkara tilang yang tidak mendapat kuasa dari pelanggar lalu lintas. ${ }^{9}$

Perma No. 12 Tahun 2016 ini juga mengatur tentang daftar berkas perkara pelanggaran lalu lintas yang dapat dilimpahkan secara elektronik (online) dari penyidik tiga hari sebelum sidang perkara tilang. Segala penetapan/putusan perkara tilang ini dipublikasikan melalui papan pengumuman yang ada di Pengadilan Negeri setempat atau website Pengadilan Negeri setempat pada hari sidang itu juga. Isi dari penetapan/putusannya berupa daftar nama pelanggar, sangkaan pelanggaran, penetapan denda pelanggaran, dan nama Hakim serta Panitera Pengganti. Dalam Pasal 7 Perma No. 12 Tahun 2016 diatur mengenai tahapan persidangan sebagai berikut: 1 . Hakim yang ditunjuk membuka sidang dan memutus semua perkara tanpa hadirnya pelanggar; 2. Hakim mengeluarkan penetapan/putusan berisi besaran denda yang diucapkan pada hari sidang yang ditentukan pada pukul 08:00 waktu setempat; 3. Penetapan/putusan denda diumumkan melalui laman resmi dan papan pengumuman Pengadilan pada hari itu juga; 4. Bagi yang keberatan dengan adanya penetapan/putusan perampasan kemerdekaan dapat mengajukan perlawanan pada hari itu juga.

Pelaksanaan putusan dalam perkara pelanggaran lalu lintas sesuai Pasal 9 Perma No. 12 Tahun 2016 dilakukan oleh Jaksa. Sedangkan Pasal 10 Perma Nomor 12 Tahun 2016 mengatur mengenai pembayaran denda dan pengambilan barang bukti sebagai berikut: 1. Pelanggar membayar denda secara tunai atau elektronik ke rekening Kejaksaan; 2. Pelanggar mengambil barang bukti kepada Jaksa selaku eksekutor di kantor Kejaksaan dengan menunjukkan bukti pembayaran denda.

Tahapan selanjutnya adalah Panitera Pengganti memasukkan data pelanggaran yang telah diputus Hakim ke dalam SIPP, setelah itu menyerahkan berkas kepada Petugas Register. Data pelanggaran yang telah diputus paling sedikit memuat nama pelanggar, pasal pelanggaran, tanggal putusan, besaran denda yang dijatuhkan, barang bukti, biaya perkara, catatan

${ }^{9}$ Agus Sahbani. (2016). "Perma Perkara Tilang Terbit, Ini Poin Yang Layak Anda Ketahui". http://www.hukumonline.com/ berita/baca/lt585a 7019 e0a5d/perma-perkara-tilang-terbit--inipoin-yang-layak-anda-ketahui, diakses pada tanggal 5 Juli 2017. pelanggaran, dan status kehadiran pelanggar. Petugas mengunggah data pelanggaran ke laman resmi Pengadilan pada hari yang sama dengan persidangan. Panitera menyerahkan berkas pelanggaran yang telah diputus kepada Jaksa pada hari yang sama dengan persidangan. Dengan adanya aturan dalam Perma, maka proses persidangan tilang dilakukan tanpa perlu hadirnya pelanggar. Hakim yang ditunjuk untuk memimpin persidangan, cukup melihat berkas perkara tilang, melihat pasal pelanggaran untuk kemudian menyatakan terbukti secara sah dan menyakinkan bersalah dan menentukan pidana yang dijatuhkan kepada pelanggar atas pelanggaran yang dilakukan. Selanjutnya, putusan hakim tersebut yang biasanya berupa pidana denda, langsung dapat diketahui, baik secara langsung melalui papan pengumuman maupun melalui halaman resmi website pengadilan yang bersangkutan.

Pelanggar yang telah mengetahui putusan pengadilan atas pelanggaran lalu lintas yang dilakukannya, kemudian datang ke Kejaksaan untuk memenuhi isi putusan atau membayar denda sebagaimana telah diputus hakim, pelanggar dapat membayar denda langsung di Kejaksaan ataupun melalui mekanisme transfer ke rekening bank yang ditentukan, untuk selanjutnya mengambil barang bukti yang ditahan. Dengan aturan baru tersebut, pelanggar tidak perlu lagi datang ke pengadilan untuk mengikuti sidang. Pelanggar cukup datang ke pengadilan untuk mengetahui putusan yang dijatuhkan. Pelanggar hanya dapat mengikuti persidangan, dalam bentuk upaya keberatan apabila tidak menerima putusan yang berupa perampasan kemerdekaan yang dijatuhkan hakim. Apabila putusan berupa pidana denda, maka terhadap apa yang diputuskan oleh pengadilan tersebut tidak dapat dilakukan upaya hukum.

\section{Efektifitas Pemberlakuan Perma No. 12 Tahun 2016}

Menurut penulis, masih terdapat banyak kekurangan dalam penerapan Perma ini terkait dengan pelaksanaan penyelesaian perkara pelanggaran lalu lintas tanpa hadirnya pelanggar. Salah satu yang menjadi permasalahan adalah bagaimana jika pelanggar yang ditilang tidak merasa bersalah, pastinya pelanggar tidak dapat melakukan pembelaan diri di depan hakim dikarenakan proses penyelesaian 
pelanggaran lalu lintas dilaksanakan tanpa kehadiran pelanggar. Di dalam Perma No. 12 Tahun 2016, upaya hukum berupa perlawanan (verzet) dapat dilakukan ketika pidana yang dijatuhkan terhadap pelanggar berupa pidana perampasan kemerdekaan. Apabila hanya dikenakan pidana denda, maka pelanggar tidak dapat melakukan upaya hukum. Upaya hukum yang dapat dilakukan oleh pelanggar terhadap putusan yang sudah inkracht termasuk dan tidak terbatas pada putusan (verstek) perkara tilang yang menjatuhkan pidana denda, apabila pelanggar merasa keberatan, yaitu upaya hukum luar biasa (berupa Peninjauan Kembali).

Menurut penulis, apakah hal tersebut tidak melanggar asas praduga tak bersalah. Karena seseorang dianggap bersalah apabila sudah ada putusan tetap dari pengadilan. sehingga sebelum adanya putusan tetap dari pengadilan, maka pelanggar belum bisa dikatakan bersalah, oleh karena itu pelanggar mempunyai hak untuk membela diri. Sebaiknya di dalam Perma No. 12 Tahun 2016 diatur tentang upaya hukum bagi pelanggar yang merasa tidak bersalah atau memberikan kesempatan terhadap pelanggar untuk membuktikannya di dalam persidangan, karena bagaimanapun juga penyelesaian perkara pelanggaran lalu lintas tidak bisa sepenuhnya dikeluarkan dari proses pengadilan. Pengadilan merupakan lembaga untuk mencari keadilan, sehingga sudah sepantasnya dalam menjatuhkan putusan, hakim harus mendengarkan terlebih dahulu penjelasan-penjelasan dari pihak yang berperkara. Sangat sulit untuk mengeluarkan perkara pelanggaran lalu lintas dari Pengadilan.

Selain regulasi, kesiapan lembaga-lembaga terkait yang menjalankan mekanisme proses penyelesaian perkara pelanggaran lalu lintas harus benar-benar dipersiapkan. Jangan sampai karena alasan agar lebih praktis harus melanggar ketentuanketentuan yang dalam Kitab Hukum Acara Pidana dan mengesampingkan keadilan bagi pelanggar. Selain hal tersebut di atas, yang perlu menjadi perhatian adalah sebagaimana yang terjadi dilapangan saat ini. Seperti yang penulis lihat di lapangan yaitu dengan sistem baru ini, tidak lagi terlihat antrian yang berjubel di Pengadilan Negeri, tetapi pemandangan baru dapat dilihat di setiap Kejaksaan Negeri. Masyarakat yang dulunya antri untuk menunggu giliran sidang, saat ini mereka antri di Kejaksaan Negeri untuk membayar denda dan mengambil barang bukti.

Menurut penulis, dalam sistem yang baru ini yang terlihat adalah mengalihkan beban dari pengadilan ke institusi yang lain, sehingga penulis menilai sistem yang baru ini belum cukup efektif.

\section{PENUTUP \\ Kesimpulan}

Proses penyelesaian perkara pelanggaran berdasarkan Perma No. 12 Tahun 2016 yaitu pelanggar lalu lintas tidak perlu lagi mengikuti proses persidangan di pengadilan. Pelanggar cukup melihat secara online atau dapat melihat langsung di papan pengumuman yang ada di Pengadilan Negeri untuk mengetahui putusan hakim atas pelanggaran yang telah dilakukan pelanggar. Setelah pelanggar mengetahui hasil putusan Hakim, selanjutnya pelanggar dapat membayar denda tersebut melalui bank yang telah ditunjuk atau membayar langsung ke kejaksaan untuk selanjutnya mengambil barang bukti di Kejaksaan. Menurut penulis, masih terdapat banyak kekurangan dalam penerapan Perma No. 12 Tahun 2012, salah satunya terkait dengan pelaksanaan penyelesaian perkara pelanggaran lalu lintas tanpa hadirnya pelanggar. Salah satu yang menjadi permasalahan adalah bagaimana jika pelanggar yang ditilang tidak merasa bersalah, pastinya pelanggar tidak dapat melakukan pembelaan diri dikarenakan proses penyelesaian pelanggaran lalu lintas dilaksanakan tanpa kehadiran pelanggar. Terkait dengan upaya hukum, di dalam Perma No. 12 Tahun 2016, upaya hukum berupa perlawanan (verzet) hanya dapat dilakukan ketika pidana yang dijatuhkan berupa pidana perampasan kemerdekaan dan bukan pidana denda. Pelanggar yang merasa keberatan tetap dapat melakukan upaya hukum terhadap putusan yang sudah berkekuatan tetap yaitu berupa upaya hukum luar biasa yang berupa peninjauan kembali.

\section{Rekomendasi}

Sebaiknya di dalam Perma No. 12 Tahun 2016 diatur tentang upaya hukum bagi pelanggar yang merasa tidak bersalah atau memberikan kesempatan terhadap pelanggar untuk membuktikannya di dalam persidangan, karena bagaimanapun juga penyelesaian 
perkara pelanggaran lalu lintas tidak bisa sepenuhnya dikeluarkan dari proses persidangan pengadilan.

Pengadilan merupakan lembaga untuk mencari keadilan, sehingga sudah seharusnya dalam menjatuhkan putusan harus mendengarkan terlebih dahulu penjelasan-penjelasan dari pihak yang berperkara. Hendaknya di dalam Perma No. 12 Tahun 2016 juga diatur mengenai upaya hukum berupa Peninjauan Kembali seperti yang telah diatur dalam Undang-Undang No. 22 Tahun 2009 tentang Lalu Lintas dan Angkutan Jalan.

Penerapan Perma No. 12 Tahun 2016 dinilai sangat efektif bagi hakim tentunya bagi Pengadilan Negeri juga. Hal tersebut dikarenakan pengadilan tidak perlu lagi melaksanakan persidangan perkara lalu lintas satu per satu seperti sebelumnya. Tetapi apakah proses tersebut juga dinilai efektif untuk instansi lainnya seperti kejaksaan. Pada kenyataannya sekarang ini penumpukan pelanggar terjadi di Kejaksaan Negeri setiap proses pengambilan barang bukti. Sehingga dapat dikatakan bahwa Perma ini efektif bagi pengadilan, tapi kurang efektif untuk Kejaksaan.

Berdasarkan hal tersebut, tentunya dibutuhkan kerjasama antar instansi agar proses penyelesaian perkara pelanggaran lalu lintas berjalan efektif bagi semua instansi terkait.

\section{DAFTAR PUSTAKA}

\section{Peraturan Perundang-Undangan:}

Kitab Undang-Undang Hukum Acara Pidana.

Undang-Undang Nomor 22 Tahun 2009 tentang Lalu

Lintas dan Angkutan Jalan.

Peraturan Pemerintah Nomor 80 Tahun 2012 tentang

Tata Cara Pemeriksaan Kendaraan Bermotor di
Jalan dan Penindakan Pelanggaran Lalu Lintas dan Angkutan Jalan.

Peraturan Mahkamah Agung Nomor 12 Tahun 2016 tentang Tata Cara Penyelesaian Perkara Lalu Lintas.

Surat Kesepakatan Bersama antara Ketua Mahkamah Agung, Menteri Kehakiman, Jaksa Agung, dan Kepala Kepolisian tentang Tata Cara Penyelesaian Perkara Pelanggaran Lalu lintas Jalan Tertentu yang ditandatangani pada 19 Juni 1993.

\section{Buku:}

Farouk Muhammad. (1999). Praktik Penegak Hukum (Bidang Lalu Lintas). Jakarta: Balai Pustaka.

M. Yahya Harahap. (2010). Pembahasan Permasalahan dan Penerapan KUHAP. Cetakan ke 12. Jakarta: Sinar Grafika.

Tim Peneliti. (2015). Standarisasi Pengelolaan Perkara Pelanggaran Lalu Lintas di Pengadilan Negeri. Jakarta: Pusat Studi Hukum dan Kebijakan Indonesia.

\section{Jurnal:}

Ari Purwadi. (1997). "Displin Lalu Lintas dan Problemanya". Perspektif. Volume 2 No. 1 Tahun 1997 Edisi April. h. 13-22. DOI: http://dx.doi. org/10.30742/perspektif.v2i1.127

\section{Website:}

Agus Sahbani. (2016). "Perma Perkara Tilang Terbit, Ini Poin Yang Layak Anda Ketahui". http://www. hukumonline.com/berita/baca/lt585a7019e0a5d/ perma-perkara-tilang-terbit--ini-poin-yanglayak-anda-ketahui, diakses pada tanggal 5 Juli 2017. 